\title{
PELATIHAN PEMBUATAN MASKER KAIN BERBAHAN KATUN AMBOSE DALAM PENCEGAHAN PENYEBARAN COVID-19 BERSAMA MANDIRI TAILOR MALANUZA NGADA
}

\author{
Efrida Ita ${ }^{1}$, Elisabeth Tantiana Ngura ${ }^{2}$ \\ 1,2,)Pendidikan Guru PAUD, STKIP Citra Bakti \\ ${ }^{1)}$ evoletelvo@gmail.com, ${ }^{2)}$ elisabethngura@gmail.com
}

\section{Histori artikel}

Received:

22 Februari 2021

Accepted:

31 Maret 2021

Published:

19 April 2021

\begin{abstract}
Abstrak
Di masa pandemi COVID 19 saat ini masyarakat wajib menggunakan masker pada saat beraktivitas di luar rumah guna membantu mencegah penularan penyebaran COVID 19. Hal tersebut menyebabkan tingginya permintaan masker. Namun, persediaan masker masih terbatas dari segi jumlah. Oleh karena itu, dilakukan kegiatan pengabdian kepada masyarakat berjudul Pelatihan Pembuatan Masker Kain Berbahan Katun Ambose Dalam Pencegahan Penyebaran Covid-19 Bersama Mandiri Tailor. Tujuan kegiatan pengabdian masyarakat ini adalah melatih para staf menjahit kain untuk membantu persediaan masker dalam rangka pencegahan penularan COVID 19. Kegiatan pengabdian ini dilaksanakan dengan melakukan pelatihan dan pendampingan secara intens bagi para staf selama satu bulan oleh instruktur menjahit melalui beberapa tahap dimulai dari menyeting mesin jahit, menggambar pola, menggunting, dan menjahit masker. Proses pelatihan telah memberikan staf keterampilan membuat masker dan menghasilkan persediaan masker sejumlah 19.066 buah yang telah didistribusikan ke beberapa instans.
\end{abstract}

Kata-kata Kunci: pelatihan pembuatan masker, pandemi COVID 19 , pencegahan penyebaran virus 
Abstract. During the Covid 19 pandemic, people are currently required to wear masks when doing activities outside the home to help prevent the spread of Covid 19. This has led to a high demand for masks. However, the supply of masks is still limited in terms of quantity. Therefore, community service activities were carried out entitled the Training on Making Cloth Masks Made from Cotton Ambose in Preventing the Spread of Covid-19 with Mandiri Tailor. The purpose of this activity is to train staff to sew in order to produce cloth masks for the community to help prevent the transmission of Covid 19. This service activity is carried out by conducting intense training and mentoring for staff for one month by sewing instructors through several stages starting from setting up the machine sewing, drawing patterns, cutting and sewing masks. The result of this training activity is the availability of sufficient cloth masks.

Keywords: training on making cloth masks, COVID 19 pandemic, prevention and transmission

\section{PENDAHULUAN}

Sejak akhir tahun 2019 sampai saat ini berita memilukan seputar mewabahnya corona virus disease (COVID-19) yang melanda hampir di seluruh belahan dunia menjadi topik tervital. Covid-19 bermula di Wuhan, Cina dan telah diumumkan sebagai pandemic oleh organisasi kesehatan dunia (Darmalaksana, dkk, 2020: 1). Pandemi ini telah menyebabkan pemerintah diberbagai belahan dunia menerapkan sejumlah kebijakan untuk mencegah penularan serta dampak ikutannya, tidak terkecuali pemerintah Republik Indonesia.

Wabah mematikan ini mengharusnya pemerintah untuk cepat berpikir melahirkan langkah-langkah preventif guna meredam penyebarannya. Beberapa langkah-langkah preventif yang disosialisaikan oleh pemerintah kepada masyarakat agar diterapkan sebagai strategi-strategi meminimalisir penyebaran wabah virus antara lain social distancing (pembatasan jarak sosial), kebijakan bekerja, belajar, beribadah dari rumah, dan penggunaan alat-alat kesehatan. Salah satu alat kesehatan tersebut adalah masker.

Masker wajib digunakan oleh masyarakat jika akan melakukan aktivitas-aktivitas di luar rumah. Hal ini merupakan anjuran dari Organisasi Kesehatan Dunia yang harus diikuti oleh semua warga negara. Bagi masyarakat yang tidak menggunakan masker pada saat bepergian akan dikenakan denda oleh petugas. Namun, pada kenyaataannya keterbatasan penyediaan masker yang dibutuhkan dan cukup berstandar menjadi kendala bagi masyakarat, secara khusus warga masyarakat Ngada dan sekitarnya. Sehubungan dengan kondisi tersebut sangat perlu diproduksi alat kesehatan berupa masker kain guna membantu masyarakat dalam pencegahan penyebaran corona virus. Pembuatan masker kain ini menjadi solusi guna menjawabi kebutuhan masyarakat tersebut. Oleh karena itu, kegiatan pengabdian kepada masyarakat dilakukan terkait dengan pembuatan masker kain berbahan katun ambose bekerja sama dengan Mandiri Tailor.

Berdasarkan latar belakang di atas, maka dilakukan pengabdian kepada masyarakat berjudul, "Pelatihan Pembuatan Masker Kain Berbahan Katun Ambose Dalam Pencegahan Penyebaran Covid-19 Bersama Mandiri Tailor Malanuza Ngada." Berdasarkan analisis kondisi tersebut teridentifikasi masalah pengabdian kepada masyarakat ini antara lain: 1) 
masyarakat masih merasa tidak penting untuk menggunakan masker pada saat beraktivitas di luar rumah pada situasi pandemi sekarang ini, dan 2) keterbatasan penyediaan masker bagi masyarakat. Tujuan dari kegiatan pengabdian kepada masyarakat ini adalah melatih para staf untuk menjahit agar dapat menghasilkan masker kain bagi masyarakat guna membantu mencegah penularan Covid 19.

\section{METODE PELAKSANAAN}

Berdasarkan analisis terhadap situasi yang terjadi, maka solusi yang ditawarkan untuk mengatasi permasalahan tentang kekurangan alat kesehatan yaitu masker adalah melalui pelatihan pembuatan masker kain berbahan katun ambose dalam pencegahan penyebaran COVID-19 bersama Mandiri Tailor sehingga dapat memenuhi kebutuhan masyarakat akan masker. Khalayak sasaran untuk dilibatkan dalam program pengabdian pada masyarakat ini adalah para staf penjahit dan dosen-dosen.

Metode kegiatan yang digunakan dalam melaksanakan kegiatan pengabdian kepada masyarakat ini adalah berbentuk pelatihan dalam pembuatan masker kain berbahan katun ambose. Adapun rincian kegiatan yang dilakukan antara lain 1) instruktur memberikan materi tentang cara menjahit, menggambar dan menggunting pola masker, 2) praktik menggunting dan menjahit masker kain. Dari kegiatan pengabdian ini, diperoleh hasil, bahwa selama dilakukannya kegiatan pendampingan pelatihan ini, peserta dinilai mengalami kemajuan keterampilannya dalam menjahit. Dari sebelumnya, peserta belum dapat menggambar dan menggunting pola, dengan adanya pelatihan ini, mereka belajar dan kemudian keterampilan mereka meningkat. Hal ini menjadi keterampilan tambahan bagi peserta di masa pandemi Covid-19 ini.

\section{HASIL DAN PEMBAHASAN}

Kegiatan pengabdian kepada masyarakat ini dilakukan dalam bentuk pelatihan dan pendampingan berkaitan dengan proses menjahit guna menghasilkan masker kain, baik dari segi kuantitas maupun kualitas bagi masyarakat Ngada khususnya dan masyarakat luas pada umumnya agar dapat membantu masyarakat untuk mencegah penyebaran wabah virus corona. Kegiatan ini diikuti oleh 12 staf yang didampingi oleh 1 orang instruktur. Kegiatan ini diikuti dengan baik oleh peserta. Dengan ilmu baru yang didapat mengenai menggambar pola, menggunting, kemudian menjahit, langsung diaplikasikan sehingga dapat dilihat kemampuan atau keterampilan peserta sebelum dan sesudah mendapat pelatihan menjahit. Kegiatan pelatihan dirasa penting dan bermanfaat, dikarenakan di masa pandemi ini, pesanan masker meningkat. Keadaan ekonomi yang dirasa sulit, mendorong masyarakat untuk memiliki keterampilan. Salah satunya adalah keterampilan menjahit. 


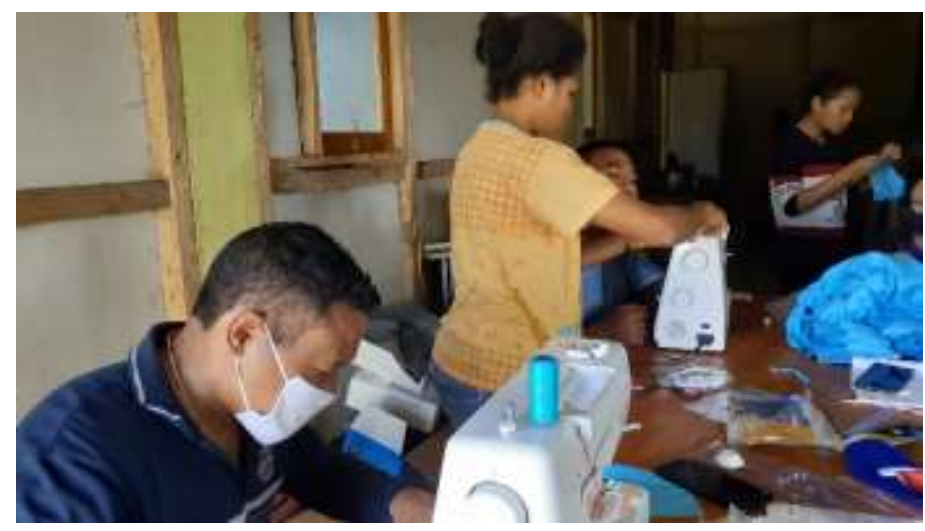

Gambar 1. Tahap Persiapan Menjahit Masker Kain

Kegiatan pengabdian ini telah direncanakan dan dilaksanakan dengan baik sesuai dengan jadwal kegiatan pada proposal kegiatan yang diawali dengan tahap persiapan terdiri dari cara menyetel mesin jahit dan cara menggunakan mesin jahit seperti terlihat pada Gambar 1.

Kegiatan pelatihan ini dimulai pada pukul 08.00 Wita dan berakhir pada pukul 17.00 Wita bertempat di ruang jahit Mandiri Tailor. Penyampian materi pelatihan dilakukan selama 30 menit oleh instruktur. Setelah dipahami oleh peserta, dilanjutkan dengan proses menjahit masker kain tersebut. Dimulai dari menggambar pola, menggunting kain sesuai dengan pola, dan menjahit sampai pada pemasangan karet masker. Tahap-tahap tersebut menjadi urutan dari proses pembuatan masker kain.

Kegiatan pelatihan ini dilaksanakan selama 4 bulan, dari bulan Maret sampai dengan bulan Juni dengan target yang ditentukan oleh penanggung jawab pelatihan berdasarkan pesanan dari berbagai lembaga. Penggunaan 6 mesin jahit mendukung untuk mempercepat target yang dipesan. Di samping kerja sama dan kedisiplinan dari para peserta pelatihan.

Target masker kain yang harus dihasilkan sejumlah 500 buah setiap hari untuk pesanan sebanyak 19.066 buah. Pembagian tugas dilakukan oleh penanggung jawab agar setiap peserta bertanggung jawab atas tugasnya masing-masing sehingga proses menjahit dapat berjalan dengan lancar guna mencapai target yang disepakati.
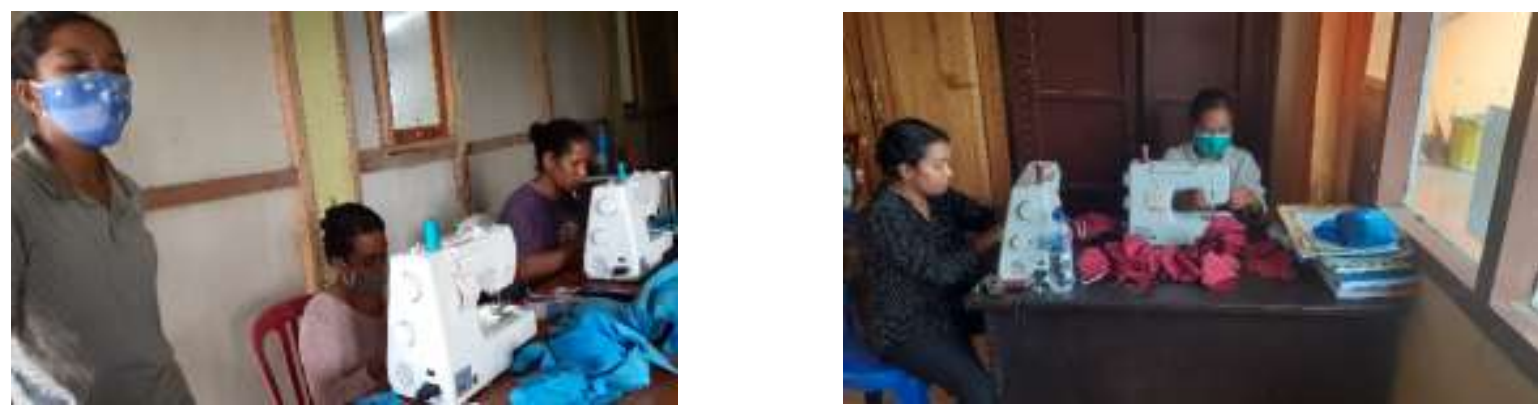

Gambar 2. Proses Menjahit Masker Kain 

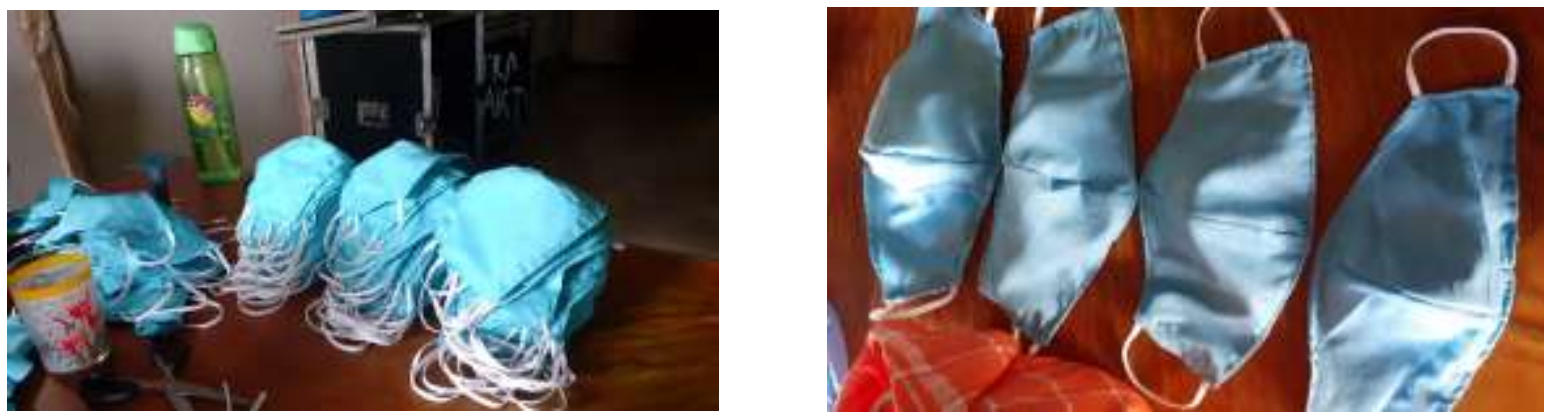

\section{Gambar 3. Masker Kain yang Telah Dihasilkan}

Masker yang telah dihasilkan sebanyak 19.066 buah dan telah terdistribusi pada beberapa instansi, baik instansi pemerintah maupun sekolah di Kabupaten Ngada dan kabupaten lainnya sehingga dapat membantu penyebaran virus corona. Oleh karena itu, kewajiban pemerintah kepada masyarakat untuk menggunakan masker pada saat beraktivitas di luar rumah dapat terjawabi dengan persediaan masker kain yang dihasilkan oleh Mandiri Tailor. Melalui kegiatan pelatihan ini, selain ekonomi dan kesehatan masyarakat menjadi baik, peserta juga mendapat ilmu dan keterampilan.

Pada dasarnya, keterampilan merupakan kemampuan dasar yang dimiliki dan melekat pada diri seseorang, yang kemudian dilatih, diasah serta dapat dikembangkan secara terus menerus, berkelanjutan guna menjadikan kemampuan seseorang menjadi potensial. Sama halnya dengan pendapat Gordon (1994), bahwa keterampilan merupakan sekumpulan kemampuan dalam diri seseorang yang kemudian diimplementasikan dalam bentuk kegiatan tertentu. Aktivitas yang dilakukan dapat berjalan dengan baik, apabila seseorang mendapatkan suatu pengalaman belajar dengan baik. Dari pengalaman belajar yang didapat selama masa pelatihan menjahit 4 bulan, peserta dapat dengan mudah melakukan kegiatan menjahit. Hal ini menjadikan kegitan pelatihan dengan mudah berjalan, karena pada dasarnya peserta sudah memiliki ketermapilan, hanya saja perlu untuk diasah dan dilatih kembali.

\section{KESIMPULAN}

Berdasarkan hasil pembahasan, proses pelatihan dalam pengabdian masyarakat ini telah memberikan staf keterampilan membuat masker dan menghasilkan persediaan masker sejumlah 19.066 buah yang telah didistribusikan ke beberapa instansi. Kegiatan pelatihan keterampilan menjahit dirasakan banyak memberi keterampilan dan manfaat bagi peserta yang mengikuti pelatihan karena mereka belum pernah mengikuti kegiatan serupa. Kegiatan dilaksanakan dengan metode penyampaian materi serta pelatihan dan diskusi yang kondusif. Hasil dari proses pelatihan, para peserta mengerti tentang proses menjahit dan ingin berwirausaha di bidang menjahit. 


\section{DAFTAR PUSTAKA}

Afiatin, T., Sonjaya, J. A., \& Pertiwi, Y. G. . (2013). Mudah dan Sukses Menyelenggarakan Pelatihan: Melejitkan Potensi Diri. Yogyakarta: Kanisius.

Anggraini, A. P.. (2020). Pemakaian masker saat pandemi. Diakses pada tanggal $18 \mathrm{Mei}$ 2020. https://health.kompas.com/read/2020/04/08/160000168/yang-harus-kita-pahamimengenai-pemakaian-masker-saat-pandemi?page=all.

Berlianti \& Siregar, Mastauli. (2017). Kemandirian Perempuan Melalui Keterampilan Menjahit. ABDIMAS TALENTA, 2(2), 179-186.

Darmalaksana, W., R. Yuli Ahmad Hambali, Ali Masrur, \& Muhlas. (2020). Analisis pembelajaran online masa WFH pendemic COVID-19 sebagai tantangan pemimpin digital abad 12. Karya Tulis IImiah (KTI) Masa Work From Home (WFH) Covid-19, UIN Sunan Gunung Djati Bandung.

Ida, Nur. (2017). Pengelolaan Pembelajaran Kursus Menjahit Pada Balai Latihan Kerja (BLK) Kecamatan Bacukiki Kota Parepare. Jurnal EMPOWERMENT, 6 (2), 11-19.

Nuryanto, Wahyu. (2014). Peranan Pendidikan Keterampilan Menjahit Terhadap Peningkatan Ekonomi Warga Belajar Di Lembaga Kursus Dan Pelatihan Mandiri Kecamatan Teras Kabupaten Boyolali. Jurnal Elektronik Mahasiswa Pendidikan Luar Sekolah S1, 3 (6).

Pranita, E. (2020). Masker kain hanya bisa digunakan untuk 4 jam dan cara melepaskannya. Diakses pada tanggal 15 Mei 2020. https://kesehatan.kontan.co.id/news/masker-kainhanya-bisa-digunakan-untuk-4-jam-begini-cara-benar-melepasnya?page=all 